\title{
Life and death after super typhoon Haiyan
}
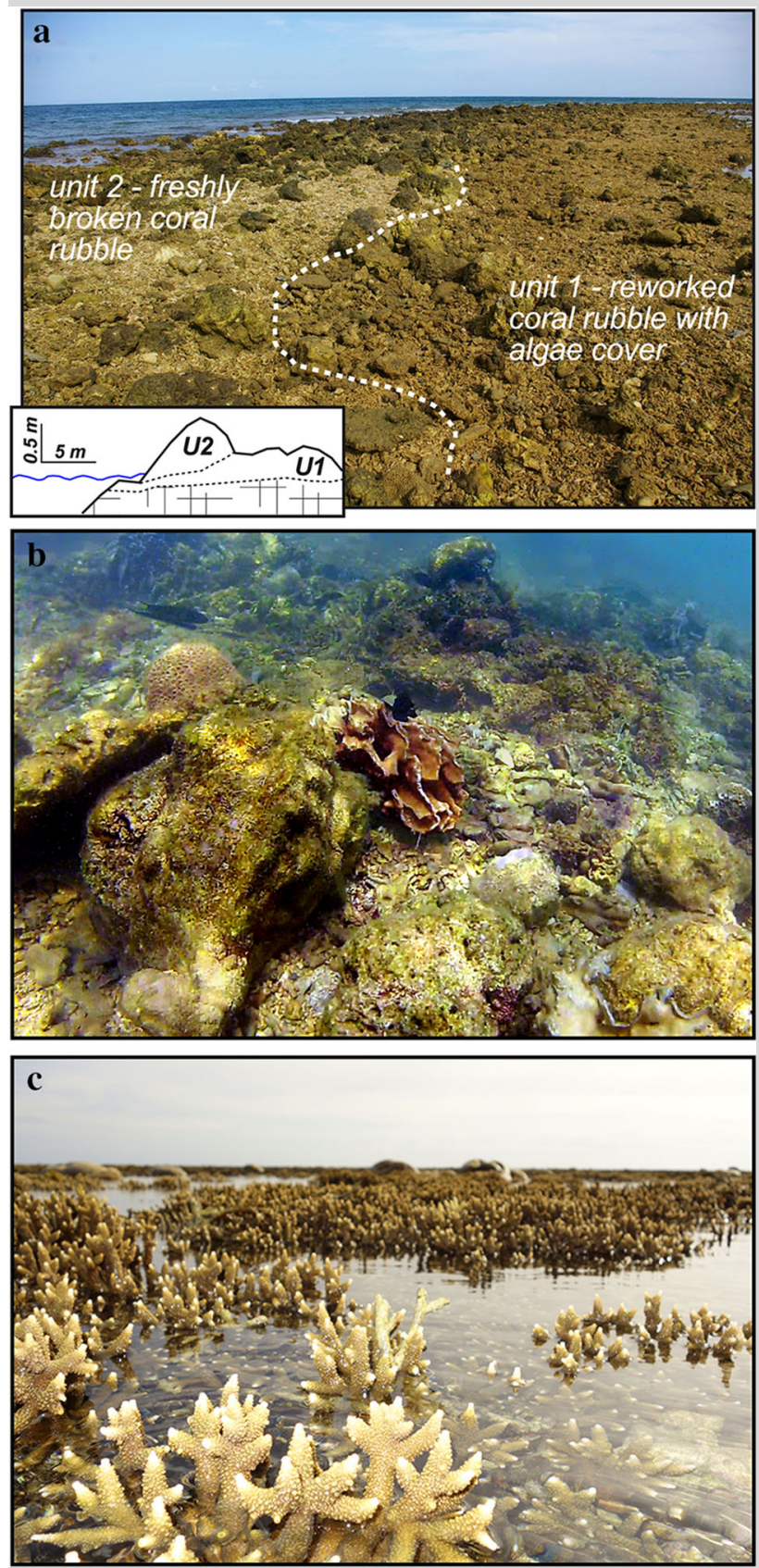

Fig. 1 a Photograph and cross section of ridge exposed at low tide. b Broken and overturned corals on Carbin's western slope.

c Live Acropora in the intertidal area
Super typhoon Haiyan, packing sustained winds $>300 \mathrm{kph}$, wrought immense damage on the Philippines in November 2013. Haiyan displaced large boulders in some areas (Engel et al. 2014) and generated an estimated $5 \mathrm{~m}$ surge in the Sagay Marine Reserve $\left(10^{\circ} 58^{\prime} 57.58^{\prime \prime} \mathrm{N}, 123^{\circ} 27^{\prime} 50.00^{\prime \prime} \mathrm{E}\right)$, central Philippines.

Immediately after, a coral boulder and rubble ridge several hundred meters long was exposed at low tide on Carbin Reef within the reserve (Fig. 1a). It was either newly established or heightened by the typhoon, but the presence of at least two different depositional units of rubble suggests the latter may be more likely.

We present an exhibition of extremes: a heavily damaged subtidal reef area (Fig. 1b) and a largely untouched intertidal coral community (Fig. 1c) separated only by the $20 \mathrm{~m}$-wide ridge. On Carbin's western slope, the typhoon displaced boulders, sheared stands of Heliopora, and overturned massive colonies down to $10 \mathrm{~m}$. Landwards of the ridge, in the shallow intertidal, many branching acroporids and massive faviids and poritids remained alive and structurally intact, consistent with observations and model predictions of Hongo et al. (2012).

Haiyan may still take its toll here, however. By February 2014, partial mortality was evident on the tips of some branching acroporids where they remain above water at low tide. Future surveys will document if the newly established or significantly heightened ridge wrought physical/ hydrological changes that could cause delayed mortality (HarmelinVivien 1994). However, the observable immediate effects of super typhoon Haiyan on Carbin demonstrate that even a category five storm is not a universal death sentence for corals in shallow habitats. Local geomorphology, exposure, and sediment dynamics merit consideration in assessing storm vulnerability, even in the shallowest of reef areas.

Acknowledgments Thanks to Dr. Laura David for survey equipment.

\section{References}

Engel M, May SM, Brill D, Reyes M, Brückner H (2014) Storm surge of supertyphoon Haiyan on Samar (Philippines) moved the largest boulder ever documented for a recent storm. AGU Fall Meeting 2014, Abstract NH21A-3824. https://agu.confex.com/agu/fm14/meetingapp.cgi\#Paper/ 10105

Harmelin-Vivien ML (1994) The effects of storms and cyclones on coral reefs: a review. J Coast Res 12:211-231

Hongo C, Kawamata H, Goto K (2012) Catastrophic impact of typhoon waves on coral communities in the Ryukyu Islands under global warming. J Geophys Res Biogeosci 117:G02029

M. Reyes ( $($ )

Marine Science Institute, University of the Philippines, 1101 Quezon City, Philippines

e-mail: michellezreyes@yahoo.com

M. Engel · S. M. May · D. Brill · H. Brueckner

Institute of Geography, University of Cologne, 50923 Cologne,

Germany 